\title{
PENGARUH INTELLECTUAL CAPITAL TERHADAP KINERJA KEUANGAN PERUSAHAAN INDUSTRI MANUFAKTUR DI BEI
}

\author{
Sandy dan Kartika Nuringsih \\ Program Studi Manajemen Fakultas Ekonomi Universitas Tarumanagara, Jakarta \\ Email : sandysell8@gmail.com
}

\begin{abstract}
The purpose of this study is to find out whether the factors of human capital, structural capital, and capital employed affect financial performance in manufactur companies listed on the Indonesia Stock Exchange in 2016-2018. This research use purposive sampling with total sample 34 data and applying the VAIC methodology to measure the effect of independent variables on dependent variable. Measure of financial performance used in this study is return on assets. The results showed that structural capital and capital employed has a positive effect significantly on financial performance. Human capital do not have effect on financial performance.
\end{abstract}

Keywords: Human Capital, Structural Capital, Capital Employed, Financial Performance

\begin{abstract}
Abstrak: Tujuan dari penelitian ini adalah untuk mengetahui apakah faktor-faktor human capital, structural capital, dan capital employed mempengaruhi kinerja keuangan perusahaan manufaktur di Bursa Efek Indonesia, tahun 2016-2018. Penelitian ini menggunakan purposive sampling dengan jumlah total sampel 34 data dan menerapkan metode VAIC untuk mengukur pengaruh variabel independen terhadap variabel dependen. Ukuran kinerja keuangan yang digunakan dalam penelitian ini adalah retrun on assets. Hasil penelitian menunjukkan bahwa structural capital, dan capital employed berpengaruh positif terhadap kinerja keuangan perusahaan, tetapi human capital tidak mempengaruhi kinerja keuangan perusahaan.
\end{abstract}

Kata Kunci: Modal Manusia, Modal Struktural, Pemakaian Modal, Kinerja Keuangan 


\section{LATAR BELAKANG}

Di era globalisasi saat ini membuat persaingan antar perusahaan semakin tinggi yang membuat perusahaan harus memikirkan cara untuk memenangkan persaingan untuk mencapai tujuan mereka. Seiring berkembangnya teknologi dan waktu yang sangat cepat membuat persaingan antar perusahaan semakin ketat. Perusahaan harus menyadari untuk memenangkan persaingan pasar, aktiva berwujud merupakan hal yang penting, tetapi aktiva tidak berwujud sama pentingnya bagi perusahaan.

Dalam perekonomian masa ini, kegiatan utama perusahaan bukan produksi barang tetapi produksi pengetahuan, yang kemudian dibangun menjadi barang dan jasa (Pulic 2008). Perekonomian saat ini pengetahuan, informasi, teknologi adalah sumber daya yang paling mendominasi di dunia (Mondal dan Ghosh 2012). Selain itu menurut Ginesti, Cardarelli, \& Zampella (2018); Berezinets et al (2016) berpendapat bahwa di era ekonomi saat ini perusahaan bersaing lebih menggunakan sumber daya tak berwujud seperti teknologi, pengetahuan, inovasi dalam proses organisasi. Aktiva tak berwujud yang berupa pengetahuan dapat meningkatkan keunggulan kompetitif dan menciptakan nilai bagi perusahaan yang disebut Intellectual capital (IC).

Menurut Komnenic dan Pokrajcic (2012) IC bukan hanya pengetahuan suatu perusahaan, IC terdiri dari Human Capital, Structural capital, dan Capital Employed. Human Capital (HC) merupakan kompetensi, kemampuan, dan inovasi karyawan dalam penataan dan penerapan untuk melakukan kegiatan tertentu. Structural Capital (SC) merupakan kemampuan perusahaan dalam infrastruktur, struktur organisasi, proses bisnis dan budaya perusahaan yang mendukung karyawan melakukan kinerja yang optimal. Capital Emlpoyed (CE) merupakan hubungan antara perusahaan dengan eksternal seperti inverstor, supplier, pelanggan, negara, dan masyarakat.

Menurut Soesanto dan Liem (2018) Indonesia sebagai negara ekonomi terbesar di Asia Tenggara, Indonesia telah memasuki masyarakat ekonomi asia (MEA) dan integrasi ekonomi regional pada tahun 2015. Indonesia perlu lebih fokus pada teknologi, pengetahuan, dan layanan kelas atas untuk mempertahankan pertumbuhan tingkat ekonomi yang tinggi setelah 2015. Perkembangan Indonesia dalam membangun knowledge based economy dapat dilihat selama tahun 2003-2012, pertumbuhan ekonomi dan lapangan kerja telah bergeser ke sektor jasa dan sektor manufaktur. Perusahaan Indonesia diharapkan untuk lebih menggunakan aset tak berwujud dalam mencapai keunggulan kompetitif. 


\section{KAJIAN TEORI}

Kinerja keuangan perusahaan sangat penting saat ini yang menjadi perhatian dan tidak bisa lepas dari perusahaan. Menurut Firer dan William (2003) kinerja perusahaan adalah fungsi penggunaan asset yang berwujud maupun yang tidak berwujud secara efektif dan efisien. Menurut Komnenic dan Pokrajcic (2012) kinerja keuangan perusahaan tidak hanya bergantung kepada investasi dalam sumber daya strategis, tetapi juga pada kemampuan perusahaan untuk menggunakannya secara efisien dalam proses value creation.

Salah satu variabel yang mempengaruhi kinerja keuangan perusahaan adalah human capital (HC). Menurut (Mention dan Bontis 2013), HC mempunyai kontribusi terhadap kinerja keuangan perusahaan baik secara langsung maupun tidak langsung dalam suatu perusahaan yang menciptakan kreativitas, dan mampu meningkatkan kepuasan pelanggan.

Variabel lainnya yang dapat mempengaruhi kinerja keuangan perusahaan adalah structural capital (SC). Menurut Komnenic dan Pokrajcic (2012) SC merupakan salah satu kunci dalam meningkatkan kinerja keuangan perusahaan dan dapat menunjukkan pertumbuhan tren yang semakin signifikan.

Selain itu ada variabel relational capital / capital employed (CE). Menurut Cheng et al, (2010) mengatakan perusahaan yang mengeluarkan biaya untuk mempertahankan hubungan dengan pelanggan untuk mewakili CE dan mereka menemukan bahwa semakin tinggi biaya yang dikeluarkan maka hubungan pelanggan yang dipertahankan semakin tinggi kemudian memiliki dampak positif bagi kinerja keuangan perusahaan.

Menurut Joshi et al (2010), IC bisa digambarkan sebagai aktiva tak berwujud yang mencipatakan keunggulan kompetitif yang berkelanjutan untuk organisasi melalui hubungan dengan sumber daya perusahaan.

Menurut Komnenic dan Pokrajcic (2012), HC tidak hanya melibatkan pengetahuan terpendam dan eksplisit dari karyawan. Ini juga mencakup komptensi dan kemampuan karyawan dalam hal penataan dan penerapan pengetahuan serta keterampilan untuk melakukan suatu kegiatan tertenu. Selain itu, dalam hasil penelitian Komnenic dan Pokrajcic (2012) mengungkapkan bahwa human capital memiliki pengaruh yang signifikan terhadap kinerja keuangan perusahaan.

Menurut Roos et al. (1997), SC mencakup semua sumber daya pengetahuan nonmanusia seperti basis data, bagan organisasi, dari proses, strategi, jadi dengan kata lain, isi masalah tersebut jauh lebih tinggi daripada nilai materialnya. Kemudian pada penelitian 
Chan (2009), selain itu Vishnu dan Gupta (2014) hasil penelitiannya mengungkapkan bahwa SC memliki pengaruh yang signifikan terhadap kinerja perusahaan.

Menurut Ting dan Lean (2009), CE didefinisikan sebagai sumber daya yang dimiliki perusahaan terkait dengan hubungan luar perusahaan seperti konsumen, pemasok atau mitra dalam penelitian dan pengembangan. Selain itu, menurut Soesanto dan Liem (2018), kemudian hasil penelitiannya mengukapkan bahwa CE memiliki pengaruh yang signifikan terhadap kinerja keuangan perusahaan.

Menurut Jumingan (2006) kinerja keuangan merupakan gambaran kondisi keuangan perusahaan dalam suatu periode tertentu yang dapat diukur dengan indikator modal, rasio likuiditas, dan profitabilitas. Menurut Sutrisno (2012:222) rasio profitabilitas adalah hasil dari kinerja manajemen perusahaan yang mengukur seberapa besar keuntungan yang didapat oleh perusahaan dalam suatu periode. Besarnya keuntungan yang didapat menunjukkan kinerja manajemen yang sangat baik dalam mengolah perusahaan.

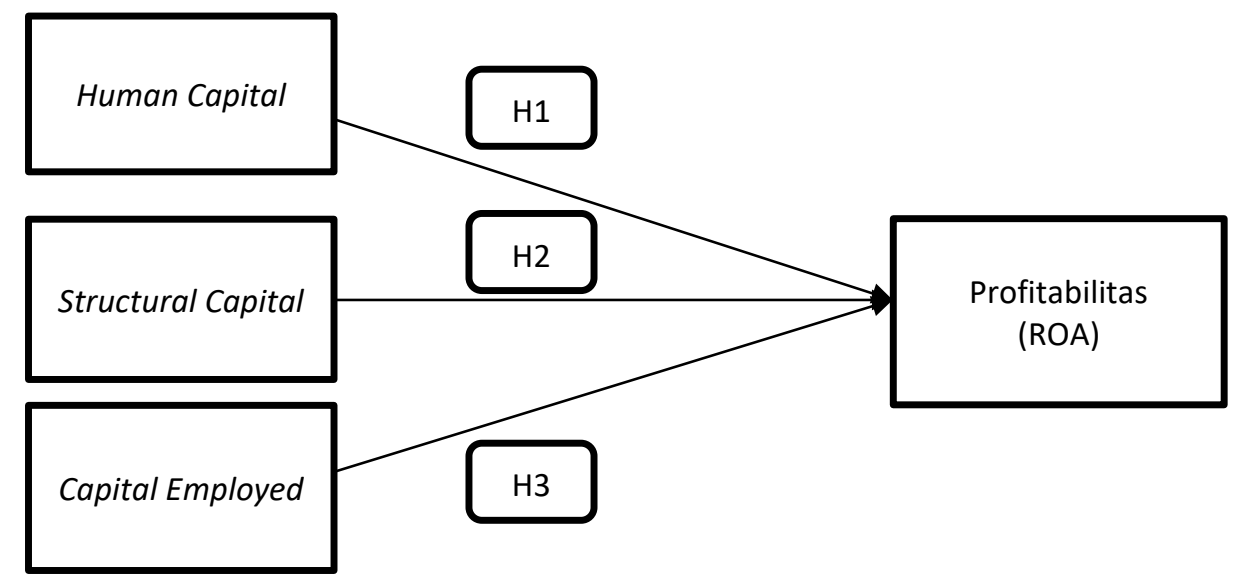

Gambar 1.0

Kerangka Pemikiran

Hipotesis dari model yang dibangun di atas adalah sebagai berikut:

H1 : Human capital memiliki hubungan positif signifikan terhada kinerja keuangan perusahaan.

H2 : Structural capital memiliki hubungan positif signifikan terhadap kinerja keungan perusahaan.

H3 : Capital employed memiliki hubungan positif signifikan terhadap kinerja keuangan perusahaan. 


\section{METODOLOGI}

Subyek penelitian ini adalah perusahaan industri manufaktur di Bursa Efek Indonesia Tahun 2016-2018. Laporan keuangan yang dapat diakses di www.idx.co.id. Pemilihan sampel dilakukan secara purposive sampling, dengan kriteria sebagai berikut: perusahaan manufaktur, memiliki laporan keuangan yang lengkap, dan memiliki data yang diperlukan untuk menghitung variabel-variabel dalam penelitian ini yang terdaftar di BEI periode 2016-2018. Jumlah perusahaan yang memenuhi kriteria adalah 34 perusahaan.

Obyek dalam penelitian ini ada satu variabel dependen dan tiga variabel independen. Variabel independen dalam penelitian ini adalah Human Capital (HC), Structural Capital (SC), Capital Employed (CE), dan variabel dependen dalam penelitan ini adalah Return on Assets (ROA). Penelitian ini akan menggunakan uji asumsi klasik multikolinearitas dan heteroskedastisitas kemudian akan dilakukan uji statistik deskriptif, dan pengujian data panel untuk mengetahui model yang akan digunakan. untuk pengujian hipotesis dilakukan dengan Uji t (parsial), Uji f (secara bersama-sama), dan Uji koefisien determinasi.

Untuk mengukur komponen IC digunakan metode Value Added Intellectual Capital (VAIC). Menurut Tan et al. (2008), VAIC mengukur tingkat IC perusahaan dan memberikan informasi tentang efisiensi penciptaan nilai dari aset perusahaan.

$$
\begin{aligned}
& \mathrm{HCE}=\text { Human Capital Efficiency } \\
& \mathrm{SCE}=\text { Structural Capital Efficiency } \\
& \mathrm{CEE}=\text { Capital Employed Efficiency }
\end{aligned}
$$

VA merupakan perbedaan antara output dan input perusahaan. Output merupakan pendapatan bersih perusahaan sedangkan input berisi semua biaya yang dikeluarkan perusahaan untuk menghasilkan pendapatan kecuali beban karyawan.

$$
\mathrm{VA}=\mathrm{S}-\mathrm{B}=\mathrm{NI}+\mathrm{T}+\mathrm{DP}+\mathrm{I}+\mathrm{W}
$$

$\mathrm{S}=$ Pendapatan bersih (Output).

$\mathrm{B}=$ Harga pokok penjualan (Input).

$\mathrm{NI}=$ Pendapatan setelah pajak (Net income) .

$\mathrm{T}=$ Pajak.

$\mathrm{DP}=$ Depresiasi.

$\mathrm{I}=$ Beban bunga.

$\mathrm{W}=$ Gaji karyawan. 
HCE dapat dihitung dengan rumus:

$$
\mathrm{HCE}=\frac{V A}{H C}
$$

$\mathrm{HCE}=$ Human capital efficiency.

$\mathrm{VA}=$ Value added .

$\mathrm{HC}=$ Total salaries dan wages.

SCE dapat dihitung dengan rumus :

$$
\mathrm{SC}=\mathrm{VA}-\mathrm{HC}
$$

$$
\begin{aligned}
& \mathrm{SC}=\text { Structural capital } . \\
& \mathrm{VA}=\text { Value added } . \\
& \mathrm{HC}=\text { Human capital } .
\end{aligned}
$$

SCE dicerminkan dengan rumus:

$$
\mathrm{SCE}=\frac{S C}{V A}
$$

$\mathrm{SCE}=$ Structural capital efficiency.

$\mathrm{SC}=$ Structural capital .

$\mathrm{VA}=$ Value added .

Capital employed efficiency dapat dihitung dengan rumus :

$$
\mathrm{CEE}=\frac{V A}{C E}
$$

$\mathrm{CEE}=$ Capital employed efficiency.

$\mathrm{VA}=$ Value added .

$\mathrm{CE}=$ Book value of the net asset .

\section{Hasil Uji Statistik}

Uji asumsi klasik. Pengujian ini dilakukan sebelum uji hipotesis pada model regresi. Dalam uji multikolinearitas dikatakan lolos karena memiliki nilai VIF dibawah 10, artinya bahwa semua variabel dependen dalam penelitian ini tidak memiliki multikolinearitas. 
Selain itu pada uji heteroskedastisitas dengan menggunakan Bruesch-Pagan-Godfrey, hasil pengujian ini dikatakan tidak ada heteroskedastisitas karena nilai dari uji ini melebihi dari 0.05 yang artinya tidak memiliki perbedaan atau ketidaksamaan variasi pada model regresi.

Uji statistik deskriptif menunjukkan bahwa nilai maksimum dan minimum ROA sebesar 0.920997, nilai minimum 0.000782. Untuk variabel human capital nilai maksimum 134.5100, nilai minimum 1.10000. Kemudian nilai maksimum dari structural capital sebesar 1, nilai minimum sebesar 0.090000. Selain itu nilai maksimum dari capital employed 0.949557 , nilai minimum sebesar 0.041561 .

Pengujian data panel dilakukan untuk mengetahui model persamaan yang akan dipakai. Pertama dilakukan uji chow, untuk mengetahui penelitian ini menggunakan fixed effect atau common effect, hasil pengujian chow mengungkapkan bahwa dalam penelitian akan menggunakan common effect karena nilai Cross-section Chi-square melebihi 0.05 maka dari itu pengujian ini tidak bisa dilanjutkan untuk uji Hausman.

Hasil analisis regresi berganda dapat dirumuskan pada persamaan sebagai berikut:

$$
\mathrm{ROA}=\alpha+\beta_{1} \mathrm{HCE}+\beta_{2} \mathrm{SCE}+\beta_{3} \mathrm{CEE}+\mathrm{e}
$$

Tabel 1

\section{Hasil Uji Regresi Linier Berganda}

\begin{tabular}{lcccc} 
Variable & Coefficient & Std. Error & t-Statistic & Prob. \\
\hline \hline \multicolumn{1}{c}{ C } & -0.316779 & 0.046355 & -6.833778 & 0.0000 \\
HCE_X1 & -0.000317 & 0.000514 & -0.616195 & 0.5392 \\
SCE_X2 & 0.363217 & 0.054918 & 6.613841 & 0.0000 \\
CEE_X3 & 0.683503 & 0.072940 & 9.370740 & 0.0000 \\
\hline \hline $\begin{array}{l}\text { R-squared } \\
\text { Adjusted }\end{array}$ & 0.593310 & Mean dependent var & 0.098957 \\
$\begin{array}{l}\text { R-squared } \\
\text { S.E. of } \\
\text { regression }\end{array}$ & 0.580860 & S.D. dependent var & 0.137394 \\
Sum & 0.088951 & Akaike info criterion & -1.963046 \\
squared & & & \\
resid & 0.775396 & Schwarz criterion & -1.860106 \\
Log & 104.1153 & Hannan-Quinn criter. & -1.921362 \\
likelihood & 47.65656 & Durbin-Watson stat & 2.118000 \\
$\begin{array}{l}\text { F-statistic } \\
\text { Prob(F- }\end{array}$ & 0.000000 & & \\
statistic) & & & \\
\hline \hline
\end{tabular}

Dependent Variable: ROA_Y 
Dari hasil regresi tabel 1, untuk uji f dapat dilihat dari Prob(F-Statistic) sebesar 0.00000 dibawah nilai tingkat signifikansi yaitu sebesar 0.05 artinya bahwa variabel independen (human capital, structural capital, capital employed) memiliki pengaruh secara bersama-sama terhadap variabel dependen (ROA). Untuk uji parsial dapat dilihat dari tabel 1 Prob setiap variabel dependen, pada variabel HCE (Human capital efficiency) nilai dari $p$-value sebesar (0.5392) diatas tingkat signifikansi sebesar 0.05 artinya $\mathrm{H} 1$ ditolak. Sedangkan untuk variabel SCE dan CEE mempunyai $p$-value sebesar (0.0000) dan (0.0000) dibawah tingkat signifikansi sebesar 0.05 artinya bahwa $\mathrm{H} 2$ dan $\mathrm{H} 3$ diterima. Selain itu untuk uji Koefisien Determinasi dapat dilihat dari tabel 1 dimana nilai dari $R$ Squared sebesar 0.593310 artinya bahwa variabel dependen (ROA) dapat dijelaskan oleh variabel independen (human capital, structural capital, capital employed) sebesar 58.08\%, sisanya $41.92 \%$ dapat dijelaskan oleh variabel lain yang tidak diteliti dalam penelitian ini.

\section{DISKUSI}

Hasil pengujian secara parsial menunjukkan bahwa variabel human capital tidak memiliki pengaruh yang signifikan terhadap kinerja keuangan perusahaan hal ini tidak sejalan dengan penelitian Komnenic dan Pokrajcic (2012) tetapi hal ini sejalan dengan penelitian Ginesti, Caldarelli, dan Zampella (2018) menyatakan bahwa human capital memiliki pengaruh negatif dan tidak signifikan terhadap kinerja keuangan perusahaan (ROA) di Italia. Untuk variabel structural capital menunjukkan bahwa SC memiliki pengaruh yang signifikan terhadap kinerja keuangan perusahaan hal ini sejalan dengan penelitian penelitian Chan (2009) mengungkapkan bahwa SC memiliki ikatan positif terhadap profitabilitas yang diukur dengan ROA, Dan Vishnu dan Gupta (2014) yang meneliti hubungan antara komponen IC (SC, HC, CE) terhadap kinerja keuangan 22 perusahaan farmasi di India yang diukur dengan ROA dan ROS, hasil penelitiannya mengungkapkan structural capital memiliki hubungan yang positif terhadap ROA.

Dan untuk variabel capital employed memiliki pengaruh signifikan terhadap kinerja keuangan perusahaan hal ini sejalan dengan penelitian Zeghal dan Maaloul (2010) yang mengungkapkan bahwal CE memiliki pengaruh yang signifikan terhadap kinerja perusahaan. Selain itu pada penelitian Soesanto dan Liem (2018) kemudian menurut Smriti dan Das (2018) hasil penelitiannya mengungkapkan bahwa CE memiliki pengaruh positif yang signifikan terhadap kinerja keuangan perusahaan. 


\section{KESIMPULAN}

Penelitian ini menyimpulkan bahwa human capital tidak memiliki pengaruh terhadap kinerja keuangan perusahaan, sedangkan structural capital dan capital employed memiliki pengaruh terhadap kinerja keuangan perusahaan. Penelitian ini masih menghadapi keterbatasan-keterbatasan antara lain: sampel yang digunakan hanya perusahaan manufaktur. Sampel yang dipakai sebanyak 102 perusahaan dari total 471. Periode penelitian hanya 3 tahun.

Dari hasil penelitian dan keterbatasan peneliti, maka penelitian ini menyarankan untuk menambah periode, sampel dan variabel independen untuk penelitian selanjutnya. Untuk perusahaan, sebaiknya lebih memperhatikan lagi tentang intellectual capital (human capital, structural capital, captail employed) agar perusahaan memliki daya saing yang kuat dimana persaingan semakin ketat dari tahun ke tahun. Selain itu Untuk investor lebih berhati-hati dalam menginvestasikan uangnya, dan diharapkan investor memilih perusahaan yang tepat, sehingga tidak merugikan investor dalam berinvestasi.

\section{DAFTAR PUSTAKA}

Berezinets, I., Garanina, T., \& Ilina, Y. (2016), "Intellectual capital of a board of directors and its elements: introduction to the concepts", Journal of Intellectual Capital, Vol. 17 No. 4, pp. 632-653.

Cheng, M-Y., Lin, J-Y., Hsiao, T-Y. and Lin, T.W. (2010), Invested resource, competitive intellectual capital, and corporate performance. Journal of Intellectual Capital, Vol. 11 No. 4, pp. 433-450.

Firer, S. \& Williams, S.M. (2003), "Intellectual capital and traditional measures of corporate performance", Journal of Intellectual Capital, Vol. 4 No. 3, pp. 348- 360.

Ginesti, G., Caldarelli, A., \& Zampella, A (2018). Exploring the impact of intellectual capital on company reputation and performance, Journal of Intellectual Capital, Vol. 19 Issue 5, pp 915-934

Jumingan (2006). Analisis Laporan Keuangan. Jakarta: PT. Bumi Aksara.

Komnenic, B. and Pokrajcic, D. (2012) . Intellectual capital and corporate performance of MNCs in Serbia, Journal of Intellectual Capital. Vol. 13. No.1, pp 106-119.

Mondal, A., \& Ghosh, S. K. (2012). Intellectual capital and financial performance of Indian banks. Journal of Intellectual Capital, Vol. 13(4), 515-530.

Pulic, A. (2008). The Principles of Intellectual Capital Efficiency. Croatia: Croatian Intellectual Capital Center.

Roos, J., Roos, G., Dragonetti, N. and Edvinsson, L. (1997), Intellectual Capital: Navigating in the New Business Landscape, Macmillan Business, London.

Soesanto, T., \& Lim, P. F. (2018). Intellectual capital in Indonesia: Dynamic Panel Approach. Journal of Asia Business Studies.

Tan, H.P., Plowman, D. \& Hancock, P. (2008). The evolving research on intellectual capital. Journal of Intellectual Capital. Vol. 8 No. 1, pp. 76-95. 